\title{
TAT-Hsp27 promotes adhesion and migration of murine dental papilla-derived MDPC-23 cells through $B 1$ integrin-mediated signaling
}

\author{
JONG-HWAN PARK ${ }^{1}$, JI-HYE YOON ${ }^{2}$, YOUNG-SIN LIM ${ }^{3}$, HO-KEEL HWANG ${ }^{3}$, \\ SOO-A KIM ${ }^{4}$, SANG-GUN AHN ${ }^{2}$ and JUNG-HOON YOON ${ }^{2}$ \\ ${ }^{1}$ Department of Biochemistry, College of Medicine, Konyang University, Daejeon 302-711; Departments of ${ }^{2}$ Pathology; \\ ${ }^{3}$ Conservative Dentistry, School of Dentistry, Chosun University, Gwangju 501-759; ${ }^{4}$ Department of \\ Biochemistry, Dongguk University College of Oriental Medicine, Gyeongju, 780-714, Korea
}

Received April 8, 2010; Accepted May 27, 2010

DOI: 10.3892/ijmm_00000475

\begin{abstract}
Odontoblasts are involved in tooth repair and regeneration as well as dentin formation. The aim of this study was to examine whether delivery of heat shock protein 27 (Hsp27) into cells using a TAT fusion protein system (TATHsp27) enhances adhesion and migration of murine dental papilla-derived MDPC-23 cells. Hsp27 was delivered into cells by the TAT-fusion protein system. To examine whether TAT-Hsp27 affects the viability of MDPC-23 cells, MTT assay was performed. The effect of TAT-Hsp27 on adhesion and migration of MDPC-23 cells was determined using type I collagen-coated plates and a commercial kit, respectively. In addition, a precise molecular mechanism was examined by Western blot analysis and focal adhesion activity. TAT-fusion protein system delivered Hsp27 into cells successfully. Transduction of TAT-Hsp27 induced adhesion and migration of MDPC-23 cells in a dose-dependent manner. Moreover, transduction of TAT-Hsp27 increased the protein expression of $B 1$ integrin and focal adhesion formation, and induced phosphorylation of FAK and ERK. TAT-Hsp27-induced migration of MDPC-23 cells was restored by treatment of antiB1 integrin antibody. These findings suggest that TAT-Hsp27 promotes adhesion and migration of MDPC-23 cells via $\beta 1$ integrin-mediated signaling and is a promising candidate for therapeutic application of dental pulp regeneration.
\end{abstract}

\section{Introduction}

Heat shock proteins (Hsps) are a class of conserved and stressinducible proteins (1). Hsps play critical roles in signal trans-

Correspondence to: Dr Jung-Hoon Yoon or Dr Sang-Gun Ahn, Department of Pathology, School of Dentistry, Chosun University, 375 Seosuk-dong, Dong-gu, Gwangju 501-759, Korea

E-mail: jhyoon@chosun.ac.kr

E-mail: ahnsg@chosun.ac.kr

Key words: dental pulp cells, adhesion, migration, TAT-heat shock protein 27, $\beta 1$ integrin duction, cell cycle regulation, and cell proliferation through their activities involved with protein folding, trafficking, degradation, and the fostering of signaling responses $(1,2)$ According to their molecular size, Hsps have been divided into several families, Hsp100, Hsp90, Hsp70, Hsp60, Hsp40, and low molecular mass Hsps (3).

Hsp27 is a member of the heat shock protein family and is induced in response to a variety of stresses including oxidative stress $(4,5)$. Hsp27 also takes part in cellular protection by preventing apoptosis via direct binding to either cytochrome $\mathrm{c}$ or procaspase-3 $(6,7)$. In addition, Hsp27 promotes adhesion, invasion, and migration in a variety of mammalian cell types (8-11).

Regeneration of a functional and living tooth is considered the most promising therapeutic strategy for the replacement of damaged teeth (12-14). Dental pulp cells and/or odontoblasts are involved in tooth repair and regeneration as well as dentin formation. Cell adhesion and migration are critical for the regeneration process in a variety of physiological and pathological conditions as well as tumor metastasis. It has been shown that Hsp27 is involved in the cell death of dental pulp cells during stress because of modification and activation (15). Although Hsp27 regulates cell migration and adhesion in wound healing or cancer cell migration $(9,16)$, the precise function of Hsp27 in dental pulp cells remains to be fully elucidated.

The TAT protein of the human immunodeficiency virus 1 (HIV-1) has been shown to be transduced efficiently into mammalian cells (17). Many fusion proteins utilizing this TAT leading sequence have been generated and result in effective transduction of functional proteins. This system has many advantages such as the ability to deliver proteins or nucleic acid into all types of cells and into all organs in vivo, even into the brain across the blood-brain barrier $(18,19)$. In this study, we examined the effect of Hsp27 using a TAT fusion protein system on cell migration and adhesion of murine dental papilla-derived MDPC-23 cells. Possible underlying mechanisms were also investigated. Our results showed that TAT-Hsp27 enhanced cell migration and adhesion through the phosphorylation of focal adhesion kinase (FAK), 
extracellular signal-regulated kinase (ERK), and its upstream cell surface molecule the $\beta 1$ integrin pathway.

\section{Materials and methods}

Purification of TAT-Hsp27 fusion protein. The TAT-Hsp27 expression vector was constructed as previously described (20). Briefly, TAT-fused Hsp27 protein was expressed in E. coli BL21 (DE3) pLysS cells (Invitrogen) and purified using the urea-denaturing protein purification method (20). Cells were lysed via sonication in lysis buffer $(1 \mathrm{mM}$ imidazole, $100 \mathrm{mM} \mathrm{NaCl}, 20 \mathrm{mM}$ HEPES, pH 8.0) containing $8 \mathrm{M}$ urea. Cell lysates were centrifuged at $12,000 \mathrm{x} \mathrm{g}$ for $30 \mathrm{~min}$ at $4^{\circ} \mathrm{C}$ and $1 \mathrm{ml}$ of $\mathrm{Ni}^{2+}$-NTA agarose was added to the cleared supernatant. After $2 \mathrm{~h}$ of gentle mixing at $4^{\circ} \mathrm{C}$, the resins were transferred into a column and subsequently washed three times with $10 \mathrm{ml}$ of washing buffer $(20 \mathrm{mM}$ imidazole, $300 \mathrm{mM} \mathrm{NaCl}, 50 \mathrm{mM}$ phosphate buffer, $\mathrm{pH}$ 8.0). Proteins were eluted four times with $1 \mathrm{ml}$ of elution buffer $(500 \mathrm{mM}$ imidazole, $300 \mathrm{mM} \mathrm{NaCl}, 50 \mathrm{mM}$ phosphate buffer, $\mathrm{pH}$ 8.0). Urea denaturant was removed with a Mono-Q ionic exchange column and desalinated with a PD10 Sephadex size exclusion column. Protein concentration was quantified via the Bradford assay and confirmed by SDS-polyacrylamide gel electrophoresis (PAGE).

Transduction and detection of TAT-Hsp27 fusion protein. MDPC-23 cells $(21,22)$ were cultured in Dulbecco's modified Eagle's medium (DMEM) supplemented with $10 \%$ fetal bovine serum (Gibco), $100 \mu \mathrm{g} / \mathrm{ml}$ streptomycin and 100 units $/ \mathrm{ml}$ penicillin, $100 \mu \mathrm{g} / \mathrm{ml}$ non essential amino acid at $37^{\circ} \mathrm{C}$ in a $5 \% \mathrm{CO}_{2}$ humidified incubator. One day prior to the addition of the fusion protein, cells were seeded on 12-well plates at a density of $3 \times 10^{5}$ cells $/ \mathrm{ml}$. Culture media were then removed and replaced with $1 \mathrm{ml}$ of fresh DMEM containing various doses $(0.1,0.5,1$, and $2 \mu \mathrm{g} / \mathrm{ml})$ of TAT-Hsp27. After transduction $(24 \mathrm{~h})$, cells were lysed and $25 \mu \mathrm{g}$ of total protein was loaded onto SDS-PAGE. Proteins were separated by electrophoresis and Western blotting was accomplished using an anti-Hsp27 antibody (diluted 1:1,000; Santa Cruz Biotechnology, USA).

For immunocytochemistry, transduced cells were washed twice in PBS and fixed with 4\% paraformaldehyde in PBS for 10 min. After being washed with PBS twice, cells were incubated with methanol for $2 \mathrm{~min}$. For immunostaining, cells were pre-treated for $30 \mathrm{~min}$ with 5\% BSA in PBS. Cells were then incubated with $2.5 \%$ BSA in PBS containing anti-Hsp27 antibody (diluted 1:250; Santa Cruz Biotechnology, USA) for $1 \mathrm{~h}$ and washed with PBS for $10 \mathrm{~min}$. Cells were incubated for 30 min with FITC-conjugated anti-rabbit secondary antibody (diluted 1:250; Jackson ImmunoResearch) in 2.5\% BSA containing PBS. Finally, cells were washed twice for $10 \mathrm{~min}$ with PBS and mounted with ProLong Antifade mounting medium (Molecular Probes). Fluorescence analysis was conducted by conventional fluorescence microscopy.

Cell viability assay. To examine whether TAT-Hsp27 induces cytotoxicity in MDPC-23 cells, cell viability was determined using the MTT assay. Cells were seeded into 12-well plates at a density of $1 \times 10^{5}$ cells $/ \mathrm{ml}$. Cells were cultured overnight and treated with different doses $(0.1,0.5$, and $1 \mu \mathrm{g} / \mathrm{ml})$ of TATHsp27 for an additional $24 \mathrm{~h}$. Cells were washed twice with PBS, and 3-(4,5-dimethylthiazol-2-yl)-2, 5-diphenyltetrazolium bromide reagent diluted in culture media was added. After $3 \mathrm{~h}$ incubation at $37^{\circ} \mathrm{C}$, the media were removed and $250 \mu \mathrm{l}$ of acid-isopropanol $(0.04 \mathrm{~mol} / \mathrm{l} \mathrm{HCl}$ in isopropanol) was added to dissolve formazan crystals. The optical density (OD) value of the dissolved solute was then measured by Microplate Autoreader ELISA (Bio-Tek Instruments Inc., Winooski, VT) at $570 \mathrm{~nm}$ wavelength.

Cell adhesion assay. Type I collagen (50 $\mu \mathrm{l})(50 \mu \mathrm{g} / \mathrm{ml}$; diluted in PBS) was added to each well of 96-well plates and placed at $4^{\circ} \mathrm{C}$ overnight. Subsequently, each well was rinsed with PBS and nonspecific binding sites were blocked with $1 \%$ BSA at $37^{\circ} \mathrm{C}$ for $1 \mathrm{~h}$. Cells $\left(5 \times 10^{4}\right)$ were placed in each well and allowed to adhere at $37^{\circ} \mathrm{C}$ for $30-90 \mathrm{~min}$. Various doses $(0.1$, $0.5,1$, and $2 \mu \mathrm{g} / \mathrm{ml}$ ) of TAT-Hsp27 were added to each well for $30 \mathrm{~min}$ before addition of cells. Non-adherent cells were rinsed off with PBS, and the remaining cells were fixed with $4 \%$ paraformaldehyde for $5 \mathrm{~min}$. Cells were stained with $0.5 \%$ toluidine blue in $4 \%$ paraformaldehyde for $5 \mathrm{~min}$ and finally rinsed in water. Cells were solubilized with the addition of $100 \mu \mathrm{l}$ of $1 \%$ SDS and OD was measured by a Microplate Autoreader ELISA (Bio-Tek Instruments Inc., Winooski, VT) at $595 \mathrm{~nm}$. In addition, another experiment for visualizing adherent cells was designed. For this, cells and TAT-Hsp27 were equally applied to type I collagen-coated wells with the above concentrations. After removing non-adherent cells by washing with PBS, samples were fixed with $200 \mu 110 \%$ formalin for $24 \mathrm{~h}$. Samples were processed and stained with hematoxylin and eosin for microscopic observation. Adherent cells were counted from five randomly selected areas at x200 magnification.

Cell migration assay. Cell migration assay was performed using a Chemotaxis Cell Migration Assay kit (Chemicon) according to the manufacturer's instructions. Cells were collected by trypsinization and resuspended in a serum-free medium at a density of $2.5 \times 10^{4}$ cells $/ \mathrm{ml}$. Cells were placed onto the insert and TAT-Hsp27 was added to the media. In an experiment to examine the effect of $\beta 1$ integrin on cell migration, cells were pre-incubated with $25 \mu \mathrm{g} / \mathrm{ml}$ of antiB1 integrin antibody (R\&D Systems, USA) for $20 \mathrm{~min}$. Cells were then allowed to migrate for $24 \mathrm{~h}$ at $37^{\circ} \mathrm{C}$. Cells that migrated to the lower surface of the membrane were fixed with methanol and stained with hematoxylin for $5 \mathrm{~min}$. The number of migrated cells on the lower side of the membrane was counted from five randomly selected high power fields (x200).

Western blot analysis. TAT-Hsp27-transduced cells were lysed with 2x SDS sample buffer. Proteins were resolved by SDSPAGE and transferred onto PVDF membrane. After blocking with $5 \%$ skim milk in TBS at room temperature for $1 \mathrm{~h}$, membranes were incubated with anti-HSP27, 11 integrin, FAK, pFAK, pERK, and actin antibodies (1:1,000 dilution; Santa Cruz Biotechnology, USA) at $4^{\circ} \mathrm{C}$ overnight. Membranes were then washed three times with TBS supplemented with $0.05 \%$ Tween-20 (T-PBS), followed by incubation with secondary antibody (1:5,000 dilution) at room temperature 
A

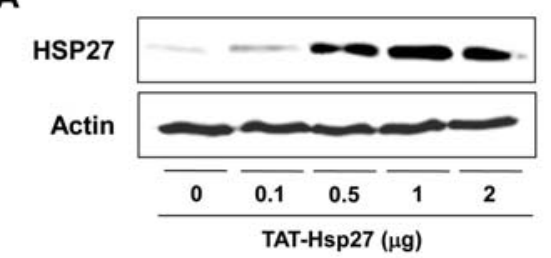

B

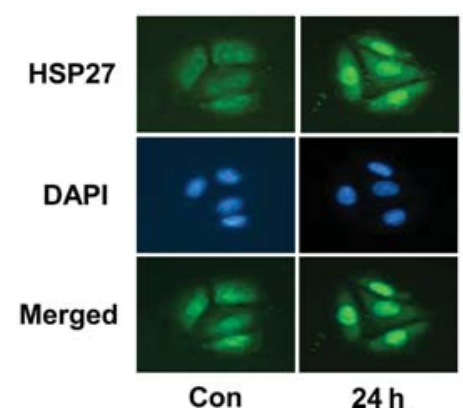

C

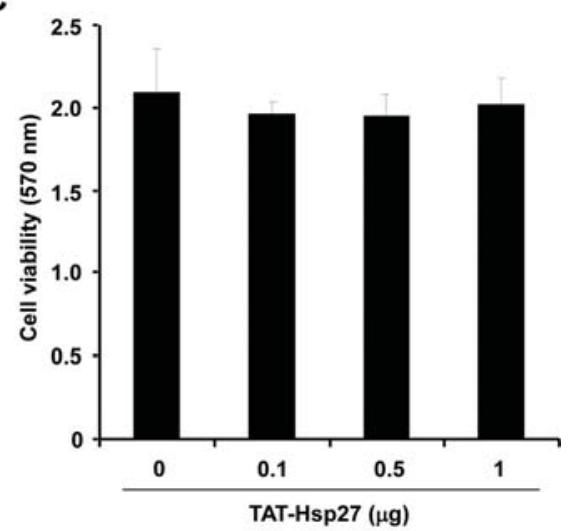

Figure 1. Transduction of TAT-Hsp27 and cell viability in MDPC-23 cells. (A) MDPC-23 cells were incubated with the indicated concentrations of TAT-Hsp27 for $24 \mathrm{~h}$. Cell lysates were prepared and the level of transduced TAT-Hsp27 was assessed by Western blot analysis using anti-Hsp27 antibody. (B) MDPC-23 cells were transduced with $1 \mu \mathrm{g}$ of TAT-Hsp27 for $24 \mathrm{~h}$. Transduced TAT-Hsp27 was visualized by immunofluorescence microscopy. The nuclei were stained with DAPI. (C) Cell viability was measured by MTT assay. The data are expressed as the means \pm SD.

A

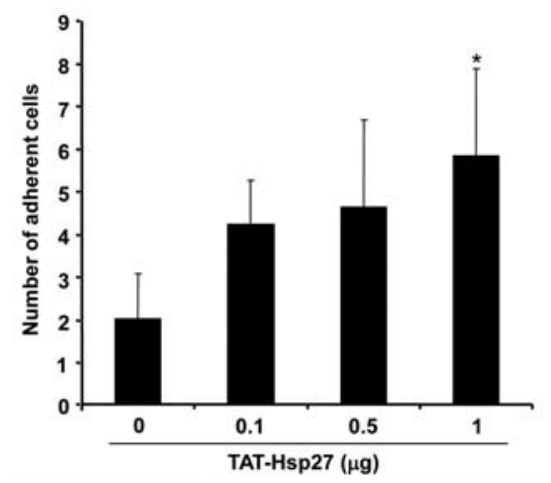

B

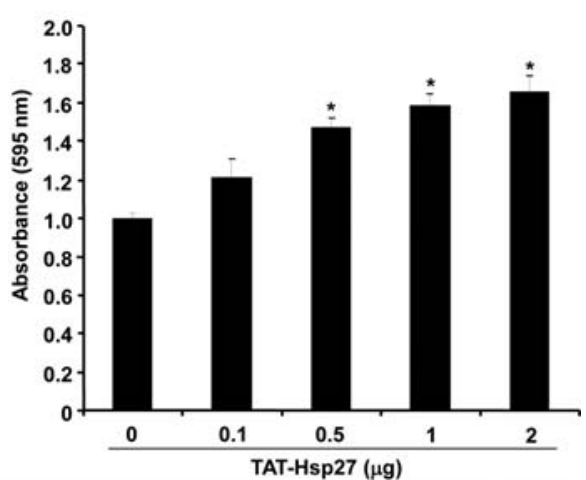

Figure 2. TAT-Hsp27 promotes the adhesion of MDPC-23 cells to type I collagen. Cells were incubated in type I collagen-coated plates in the absence or presence of TAT-Hsp27. (A) Cells adherent to type I collagen were stained with H\&E and counted from five randomly selected areas (x200 magnifications). (B) Cells adherent to type I collagen were stained with toluidine blue and solubilized with the addition of $100 \mu 1$ of $1 \%$ SDS. Finally, optical density was measured at $595 \mathrm{~nm}$. Results are expressed as the means \pm SD. ${ }^{*} \mathrm{P}<0.05$.

for 1 h. Finally, membranes were visualized with West-Zol ${ }^{\circledR}$ (plus) (Intron Biotechnology Inc., Korea) detection reagent using chemiluminescence system of LAS-1000 Image Reader of Luminescence Image Analyzer (FujiFilm Life Science, Tokyo, Japan).

Counting of focal adhesions. Cells $\left(1 \times 10^{4}\right)$ were seeded in a 4-well chamber slide, and treated with TAT-Hsp27 (0.1, 0.5, and $1 \mu \mathrm{g} / \mathrm{ml}$ ) for $24 \mathrm{~h}$. Cells were washed with cold PBS, fixed with $4 \%$ formaldehyde for $10 \mathrm{~min}$ at room temperature. After washing, cells were blocked with 5\% BSA in TBS for $30 \mathrm{~min}$, and then incubated with pFAK antibody $(1: 200$; Santa Cruz Biotechnology) in 2.5\% BSA in TBS for $2 \mathrm{~h}$. After washing, FITC-conjugated secondary antibody (diluted 1:250; Jackson ImmunoResearch) was added with DAPI solution $(1 \mathrm{mg} / \mathrm{ml})$. The number of focal adhesions per unit area was determined microscopically.
Statistical analysis. Statistical significance between groups was determined by two-way ANOVA test. Differences were considered significant at $\mathrm{p}<0.05$.

\section{Results}

Transduction of TAT-Hsp27 fusion protein and its effect on cell viability. We examined whether the TAT-Hsp27 fusion protein is capable of traversing the cytoplasmic membranes of cells. The TAT-Hsp27 protein was added to the MDPC-23 cells for $24 \mathrm{~h}$ and then the level of transduced Hsp27 was determined by Western blot analysis. TAT-Hsp27 was delivered successfully into cells in a dose-dependent manner (Fig. 1A). Immunocytochemistry also verified the significant accumulation of TAT-Hsp27 in both the cytoplasm and nucleus (Fig. 1B). In addition, to examine the effect of TATHsp27 on cell viability, MDPC-23 cells were treated with 
A

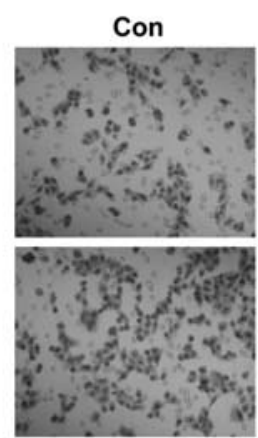

Hsp27 $0.5 \mu \mathrm{g}$
Hsp27 0.1 $\mu \mathrm{g}$

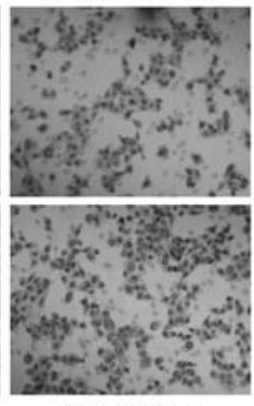

Hsp27 $1 \mu \mathrm{g}$
B

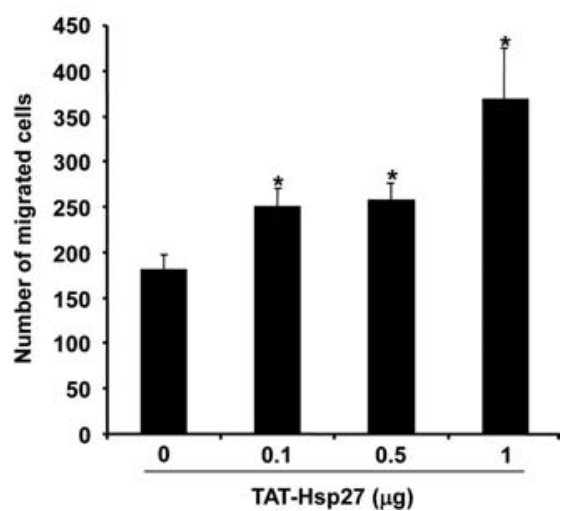

Figure 3. TAT-Hsp27 promotes migration of MDPC-23 cells. Migration assay was performed as described in Materials and methods. (A) Migrating cells were fixed with methanol and stained with hematoxylin. (B) The number of migrating cells was counted from five randomly selected areas (x200 magnification). Results are expressed as the means $\pm \mathrm{SD} .{ }^{*} \mathrm{P}<0.05$.

A

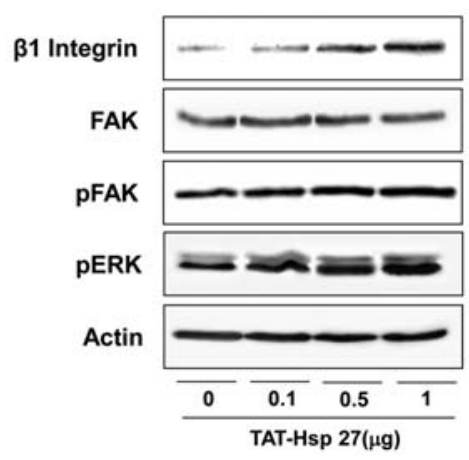

B

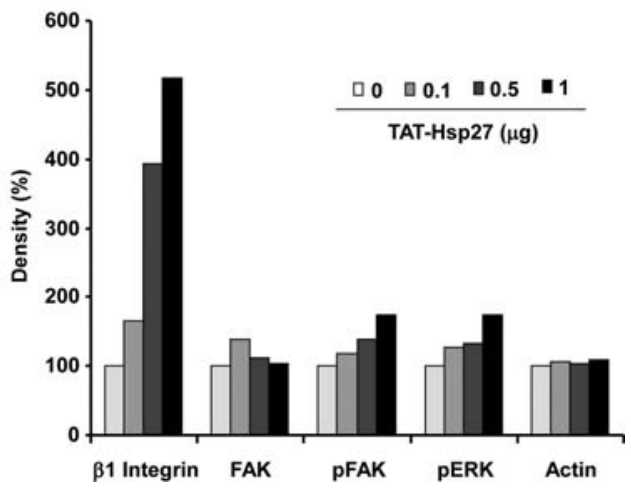

Figure 4. TAT-Hsp27 up-regulates B1 integrin and phosphorylation of its downstream FAK and ERK. (A) Cells were incubated with the indicated concentrations of TAT-Hsp27 for $24 \mathrm{~h}$. Cell lysates were prepared and the level of B1 integrin, FAK, p-FAK, ERK, p-ERK, and actin was assessed by Western blot analysis. (B) The band densities were measured and expressed as the percentage to control.

various concentrations $(0.1,0.5$, and $1 \mu \mathrm{g} / \mathrm{ml})$ of TAT-Hsp27. TAT-Hsp27 transduction at the tested concentrations did not affect the viability of MDPC-23 cells, showing $>95 \%$ cell viability (Fig. 1C). Thus, we determined this range of concentrations of TAT-Hsp27 as the doses to be used for subsequent experiments.

Effect of TAT-Hsp27 on cell adhesion and migration. Previous studies showed that Hsp27 regulates adhesion, invasion, and migration in several cell types (8-11). Therefore, we examined whether TAT-Hsp27 influences adhesion ability of MDPC-23 cells to type I collagen. Cells adherent to type I collagen were counted by microscopic observation. Additionally, adhesion was quantified by measuring toluidine blue absorbance. The number of adherent cells was significantly increased by TAT-Hsp27 in a dose-dependent manner (Fig. 2A). Moreover, toluidine blue absorbance also gradually increased in TATHsp27-transduced cells in a dose-dependent manner (Fig. 2B). Next, we examined the effect of TAT-Hsp27 on migration ability of MDPC-23 cells using a commercial cell migration assay kit. TAT-Hsp27 treatment significantly enhanced migration of MDPC-23 cells, which was also dose-dependent (Fig. 3A and B).

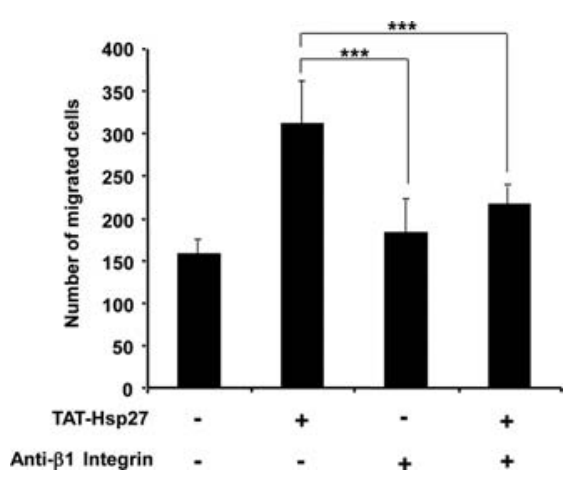

Figure 5. TAT-Hsp27-mediated migration of MDPC-23 cells is restored by anti- $\beta 1$ integrin antibody. TAT-Hsp27 was applied to MDPC-23 cells pretreated with and without anti- $\beta 1$ integrin antibody. The number of migrating cells was obtained as described in Fig. 3B. Results are expressed as the means $\pm \mathrm{SD}$. ${ }^{* * *} \mathrm{P}<0.01$.

Effect of TAT-Hsp27 on expression of $\beta 1$ integrin and phosphorylation of FAK and ERK. Because $\beta 1$ integrin and its downstream signaling are involved in cell adhesion and migration, we examined whether TAT-Hsp27 induces the 
A

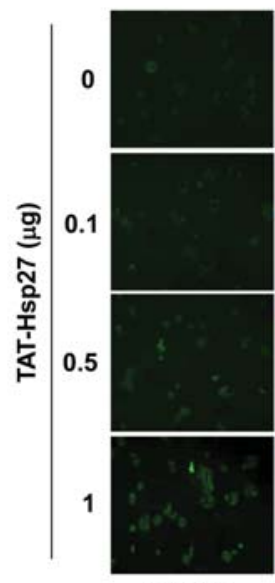

p-FAK

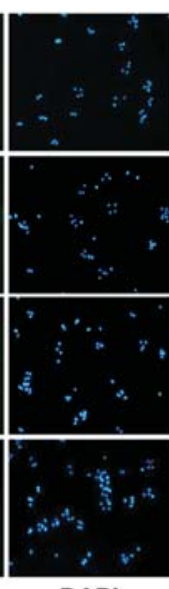

DAPI

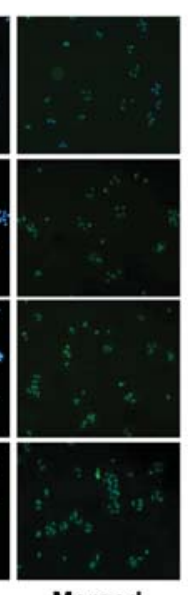

Merged
B

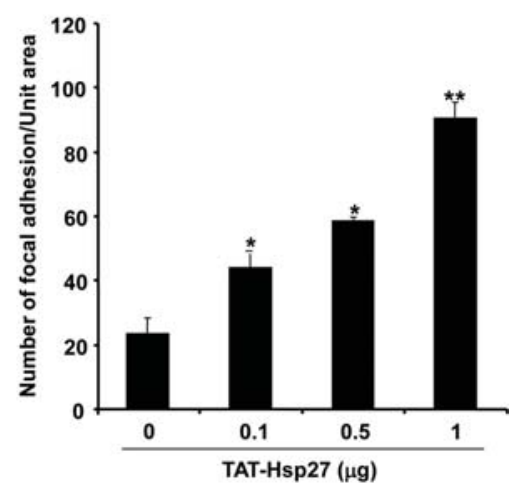

Figure 6. TAT-Hsp27 increases the formation of focal adhesion. (A) Cells were treated with different doses of TAT-Hsp27 and stained with anti-pFAK antibody. Cells were then reacted with FITC-conjugated secondary antibody with DAPI solution. (B) The number of focal adhesions per unit area was determined microscopically. Results are expressed as the means $\pm \mathrm{SD} .{ }^{*} \mathrm{P}<0.05,{ }^{* *} \mathrm{P}<0.01$. expression of $\beta 1$ integrin and the activation of FAK and ERK. TAT-Hsp27 transduction apparently induced the expression of $\beta 1$ integrin in MDPC-23 cells, which was dose-dependent (Fig. 4A and B). It also slightly increased phosphorylation of FAK and ERK (Fig. 4A and B). These findings mean that TAT-Hsp27 may modulate $\beta 1$ integrin-mediated signaling in MDPC-23 cells.

The role of $\beta 1$ integrin on TAT-Hsp27-mediated migration of MDPC-23 cells. Next, we examined whether $B 1$ integrin regulates TAT-Hsp27-mediated migration of MDPC-23 cells. Similarly to that shown in Fig. 3, TAT-Hsp27 transduction led to an increase of cell migration, which was restored by treatment of anti-ß1 integrin antibody (Fig. 5). This finding suggests that TAT-Hsp27 promotes the migration ability of MDPC-23 cells via $B 1$ integrin-mediated signaling.

Effect of TAT-Hsp27 on focal adhesion formation. Since FAK plays a crucial role in cell adhesion, we examined focal adhesion formation in TAT-Hsp27-transduced cells by immunofluorescent staining with anti pFAK antibody. TATHsp27 transduction significantly increased the number of focal adhesions of MDPC-23 cells in a dose-dependent manner (Fig. 6).

\section{Discussion}

Cell adhesion, invasion, and migration play a critical role not only in normal homeostasis such as wound healing and regeneration but also in pathological conditions including tumor progression via angiogenesis and metastasis (23). Because dental pulp cells and/or odontoblasts are responsible for tissue regeneration and dentin formation, and cell adhesion and migration are critical processes in tissue regeneration, it is valuable to clarify the precise mechanism for the adhesion and migration of dental pulp cells.

In this study, we showed that the TAT-fused Hsp27 was effectively delivered into the MDPC-23 cells. Furthermore, our results revealed that transduction of TAT-Hsp27 promoted the ability of adhesion and migration of MDPC-23 cells. The treatment of TAT-Hsp27 $(1 \mu \mathrm{g} / \mathrm{ml})$ in MDPC-23 cells increased the migratory and adhesive capacity compared with control cells. However, TAT-Hsp27 at the same concentration had no effect on proliferation or cytotoxicity. This means that enhanced cell migration and adhesion was not simply a result of an increase in the number of cells.

Human dental pulp cells and odontoblasts displayed several integrins and these integrins were thought to play a physiological role in maintaining the cohesion of the odontoblast layer necessary to the integrity of the peripheral dental pulp (24). Integrin activation has been shown to be an essential requirement for cell migration. $\beta 1$ integrin is a predominant $B$ subunit that can pair with multiple subunits to form heterodimeric integrin receptors. Association of $\beta 1$ integrin in dental pulp cell adhesion is anticipated as it has been reported to modulate adhesion and migration in several cell types. In this study, inhibitory action of an antibody against $\beta 1$ integrin on cell migration supports that such integrin is required for migration of MDPC-23 cells.

It has been shown that overexpression of Hsp27 activates integrin-mediated signaling pathways and enhances focal adhesion formation via FAK activation $(9,25)$. Phosphorylation of the MAP kinase ERK 1/2 has been linked to alterations in focal adhesion formation via stimulation of receptor tyrosine kinases (26). In the present study, we revealed that TAT-Hsp27 transduction slightly induced phosphorylation of FAK and ERK and focal adhesion formation. It is likely that TAT-Hsp27 enhances focal adhesion formation via activation of FAK and ERK.

Collectively, our findings have shown here that biologically active, exogenous Hsp27 can be delivered into cells using the HIV-1 TAT protein and promotes adhesion and migration of MDPC-23 cells. Additionally, we have demonstrated its ability to promote the phosphorylation of FAK, ERK as well as expression of $B 1$ integrin. Our results demonstrate the possibility of the effective use of TAT-Hsp27 to coat pulp capping materials to promote cell adhesion and migration for biodental applications of dentin repair or regeneration purposes. 


\section{Acknowledgements}

This study was supported by the Korea Science and Engineering Foundation (KOSEF) grant funded by the Korean government (MOST) (No. R13-2008-010-01001-0).

\section{References}

1. Feder ME and Hofmann GE: Heat-shock proteins, molecular chaperones, and the stress response: evolutionary and ecological physiology. Annu Rev Physiol 61: 243-282, 1999.

2. Parsell DA and Lindquist S: The function of heat-shock proteins in stress tolerance: degradation and reactivation of damaged proteins. Annu Rev Genet 27: 437-496, 1993.

3. Lindquist S and Craig EA: The heat-shock proteins. Annu Rev Genet 22: 631-677, 1988.

4. Jia Y, Ransom RF, Shibanuma M, Liu C, Welsh MJ and Smoyer WE: Identification and characterization of hic-5/ARA55 as an hsp27 binding protein. J Biol Chem 276: 39911-39918, 2001.

5. Lavoie JN, Gingras-Breton G, Tanguay RM and Landry J: Induction of Chinese hamster HSP27 gene expression in mouse cells confers resistance to heat shock. HSP27 stabilization of the microfilament organization. J Biol Chem 268: 3420-3429, 1993.

6. Bruey JM, Ducasse C, Bonniaud P, Ravagnan L, Susin SA, Diaz-Latoud C, Gurbuxani S, Arrigo AP, Kroemer G, Solary E and Garrido C: Hsp27 negatively regulates cell death by interacting with cytochrome c. Nat Cell Biol 2: 645-652, 2000.

7. Lee JS, Lee JJ and Seo JS: HSP70 deficiency results in activation of c-Jun $\mathrm{N}$-terminal Kinase, extracellular signalregulated kinase, and caspase- 3 in hyperosmolarity-induced apoptosis. J Biol Chem 280: 6634-6641, 2005.

8. Golembieski WA, Thomas SL, Schultz CR, Yunker CK, McClung HM, Lemke N, Cazacu S, Barker T, Sage EH, Brodie C and Rempel SA: HSP27 mediates SPARC-induced changes in glioma morphology, migration, and invasion. Glia 56: 1061-1075, 2008 .

9. Lee JW, Kwak HJ, Lee JJ, Kim YN, Lee JW, Park MJ, Jung SE, Hong SI, Lee JH and Lee JS: HSP27 regulates cell adhesion and invasion via modulation of focal adhesion kinase and MMP-2 expression. Eur J Cell Biol 87: 377-387, 2008.

10. Piotrowicz RS, Hickey E and Levin EG: Heat shock protein $27 \mathrm{kDa}$ expression and phosphorylation regulates endothelial cell migration. FASEB J 12: 1481-1490, 1998.

11. Rousseau S, Houle F, Landry J and Huot J: p38 MAP kinase activation by vascular endothelial growth factor mediates actin reorganization and cell migration in human endothelial cells. Oncogene 15: 2169-2177, 1998.
12. Chai Y and Slavkin HC: Prospects for tooth regeneration in the 21st century: a perspective. Microsc Res Tech 60: 469-479, 2003.

13. Thesleff I: Developmental biology and building a tooth. Quintessence Int 34: 613-620, 2003.

14. Yen AH and Sharpe PT: Regeneration of teeth using stem cellbased tissue engineering. Expert Opin Biol Ther 6: 9-16, 2006.

15. Kitamura C, Nishihara T, Ueno Y, Chen KK, Morotomi T, Yano J, Nagayoshi $\mathrm{M}$ and Terashita $\mathrm{M}$ : Effects of sequential exposure to lipopolysaccharide and heat stress on dental pulp cells. J Cell Biochem 99: 797-806, 2006.

16. Hirano S, Shelden EA and Gilmont RR: HSP27 regulates fibroblast adhesion, motility, and matrix contraction. Cell Stress Chaperones 9: 29-37, 2004.

17. Nagahara H, Vocero-Akbani AM, Snyder EL, Ho A, Latham DG, Lissy NA, Becker-Hapak M, Ezhevsky SA and Dowdy SF: Transduction of full-length TAT fusion proteins into mammalian cells: TAT-p27Kip1 induces cell migration. Nat Med 4: 1449-1452, 1998 .

18. Fittipaldi A and Giacca M: Transcellular protein transduction using the Tat protein of HIV-1. Adv Drug Deliv Rev 57: 597-608, 2005.

19. Rapoport M and Lorberboum-Galski H: TAT-based drug delivery system - new directions in protein delivery for new hopes? Expert Opin Drug Deliv 6: 453-463, 2009.

20. Becker-Hapak M, McAllister SS and Dowdy SF: TAT-mediated protein transduction into mammalian cells. Methods 24: 247-256, 2001.

21. Hanks CT, Sun ZL, Fang DN, Edwards CA, Wataha JC, Ritchie HH and Butler WT: Cloned 3T6 cell line from CD-1 mouse fetal molar dental papillae. Connect Tissue Res 37: 233-249, 1998.

22. Sun ZL, Fang DN, Wu XY Ritchie HH, Bègue-Kirn C, Wataha JC, Hanks CT and Butler WT: Expression of dentin sialoprotein (DSP) and other molecular determinants by a new cell line from dental papillae, MDPC-23. Connect Tissue Res 37: 251-261, 1998.

23. Dormann D and Weijer CJ: Imaging of cell migration. EMBO J 25: 3480-3493, 2006 .

24. Staquet MJ, Couble ML, Romeas A, Connolly M, Magloire H, Hynes RO, Clezardin P, Bleicher F and Farges JC: Expression and localisation of alphav integrins in human odontoblasts. Cell Tissue Res 323: 457-463, 2006.

25. Gerthoffer WT and Gunst SJ: Invited review: focal adhesion and small heat shock proteins in the regulation of actin remodeling and contractility in smooth muscle. J Appl Physiol 91: 963-972, 2001.

26. Hamilton DW and Brunette DM: The effect of substratum topography on osteoblast adhesion mediated signal transduction and phosphorylation. Biomaterials 28: 1806-1819, 2007. 